\title{
A HEURISTIC-INDUCING METHOD FOR GENERATING INITIAL IDEAS FOR OPPORTUNITIES: AN APPLICATION TO THE AUSTRALASIAN DATING MARKET
}

\author{
MARCO VAN GELDEREN \\ Department of Management @ Albany \\ Massey University, Private Bag 102904 \\ NSMC Auckland 0745, New Zealand \\ M.VanGelderen@massey.ac.nz
}

\begin{abstract}
This paper presents a heuristics-inducing method for generating initial ideas for opportunities. It consists of the presentation of snippets of theory and research, selected for their inspirational value and relevance to a particular industry, to business owners in that industry to brainstorm about applications in products and services. In this approach, the researcher bridges the worlds of academia and business, and actively contributes to the opportunity recognition process by selecting, presenting and discussing information. The method is applied to the dating market: searching, matching and/or interacting services, whether internet based or real-life. Participants were ten Australians or New Zealanders dating service owners. The presented information concerns social psychological research outcomes on factors that contribute to attraction and forming bonds, and specific issues relevant to the dating market, e.g., gender imbalances in enrollment. A range of initial ideas for future possibilities in the dating market are presented.
\end{abstract}

Keywords: Opportunity-recognition; idea-generation; dating-market.

\section{INTRODUCTION}

The discovery, evaluation, enactment, and exploitation of opportunities are recently seen as core elements of entrepreneurship (Sarasvathy, 2001; Shane and Venkataraman, 2000; Shane, 2003). As a consequence, opportunity recognition (OR) has increasingly been researched as well as practiced in educational and training settings. Methods have been explored and applied (e.g., DeTienne and Chandler, 2004; Fiet and Patel, 2008; van Gelderen, 2004, 2006), and the aim of this research is to present one such method. Its 
main characteristic is that the researcher engages with the business community by selecting, presenting and discussing theory and research on the basis of their heuristic or inspirational value, in order to generate initial ideas for opportunities. In this paper we will outline the method, position it in the OR literature, and demonstrate its value and workings by applying it in a case study of the Australasian dating market.

\section{GENERATING INITIAL IDEAS FOR OPPORTUNITIES}

Business opportunities range from simple price arbitrage to radical innovations. Opportunity recognition comprises idea generation, enactment, development, and evaluation (Sarasvathy, 2001; Shane and Venkataraman, 2000). In this paper the focus is on the 'how to' aspect of generating initial ideas. No attention is paid to opportunity enactment and development (Baker and Nelson, 2005; Dimov, 2007, Sarasvathy, 2001), evaluation (Keh, Foo and Lim, 2002), or exploitation (Choi and Shepherd, 2004).

Generating initial ideas for business opportunities is a complex process

to which several factors contribute (see Fig. 1). The notion of alertness is a

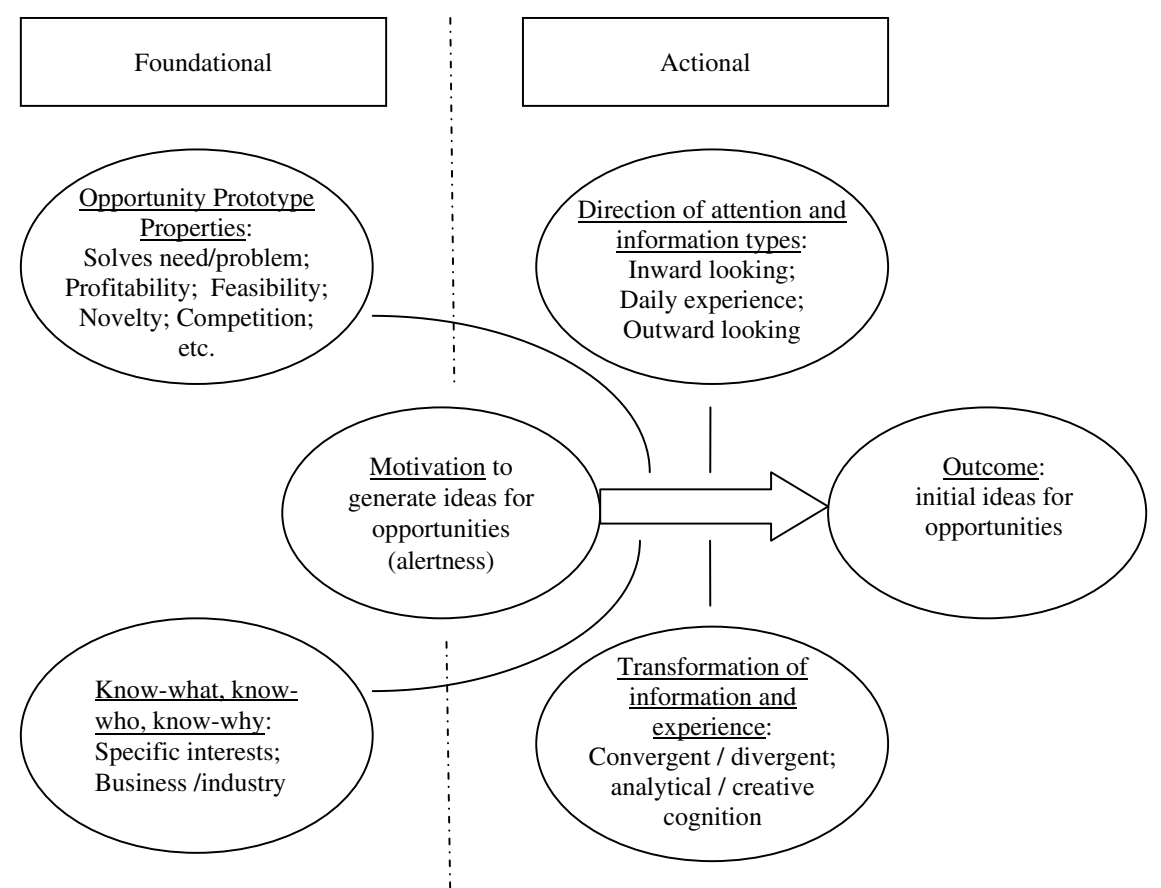

Figure 1. Generating Initial Ideas for Opportunities. 
starting point for our thinking, as it represents the motivation to see opportunities. Alertness is defined by Kirzner (1997) as an attitude of receptiveness to opportunities. In behavioral terms, one directs one's attention to signals or cues that signify opportunities. Ardichvili, Cardozo and Ray (2003) refer to a state in which one "notices and is sensitive to information, objects, incidents, and patterns in the environment, with special sensitivity to maker and user problems, unmet needs and interests, and novel combinations of resources' (p. 113). If and how motivation to see opportunities (alertness) translates into initial ideas for opportunities is affected by the four factors depicted in Fig. 1. They are the attributes and properties of an opportunity; prior knowledge, networks, and self-awareness; the direction of attention and information types; and the transformation of information and experience into ideas for opportunities. Methods for the generation of ideas for opportunities can target each of these factors, and a comprehensive method would encompass all of them. Two factors can be considered foundational: they represent what a person brings to the opportunity idea generation process. The other two factors make up the idea generation process itself. Each factor will be discussed below.

First, when generating ideas for opportunities one must have some sort of idea of what an opportunity looks like. Just as we have a mental concept 'house' to which villas and townhouses belong, but not malls and skyscrapers, so we have a mental concept or prototype of an opportunity (Baron, 2004). Examples of attributes include profitability, uniqueness, superiority, feasibility, market potential, and manageable risks (Baron and Ensley, 2006). These properties are also evaluative dimensions. Initial guesses of their content may in some cases be precise, but in other instances their actual content may only become clear over time. The attributes of such a prototype, and the weight they are given, can differ from person to person, for example depending on their entrepreneurial experience. Baron and Ensley (2006) and Ucsbarasan, Westhead and Wright (2009) all found experienced entrepreneurs to be more attracted by profitability and feasibility, and novice entrepreneurs by newness and uniqueness. The attributes and weights will also differ depending on the type of opportunity pursued: Arbitrage, franchise, imitation, take-overs, cheaper/better/faster, incremental innovation, and radical innovation opportunities.

Another factor that comes into play when generating initial ideas for opportunities is one's prior knowledge. Research indicates that knowledge and information gathered through rich and varied life, business and work experience helps to recognize opportunities (Baron, 2006). Ideas generated are typically a function of one's prior knowledge and experience (Shane, 
2000). Prior knowledge domains relevant to opportunity recognition include both business and industry knowledge as well as any special interest domain that one might have (Ardichvilli, Ray and Cardozo, 2003; Shane, 2003). Being knowledgeable in multiple knowledge domains opens up possibilities to make connections between those different domains (Ardichvilli et al., 2003; Baron, 2006). It is not only one's prior knowledge and experience that will influence ideas for opportunities, it is also one's sense of identity, work motivation, and personal meaning (know-why) and one's social networks (know-whom). They affect initial ideas for opportunities in the same way that one's accumulated prior knowledge (know-what) does. Ideas that fit well with one's aims, aspirations, and sense of identity are more likely to spring up. Not only that, they are also more likely to be actually pursued, rather than being ideas for someone else to act on (McMullen and Shepherd, 2006). Similarly, the information flowing from one's network influence what ideas a person will think of (DeCarolis and Saparito, 2006; Ozgen and Baron, 2009).

The previous two factors can be seen as foundational: whereas they influence the outcomes of the idea generation process, they are not actions to generate ideas. The third and fourth factor in Fig. 1 represent those actions. Generating initial ideas starts with directing the focus of alertness. There are basically three directions. These are not mutually exclusive and in fact inform and reinforce each other. First, it can be employed, even unintentionally, in what has been labeled 'passive search' where one is sensitive to one's daily experience of problems, surprises, successes, pleasures, annoyances, frictions, and supply/demand imbalances. These are linked to opportunities that they may imply. One does not actively seek this information (Kirzner, 1997, 2009). Still, those engaged in passive search 'position' themselves in terms of their networks, activities, and information flows (Kaish and Gilad, 1991). It is a state of mind in which one is alert to ideas for opportunities in one's daily encounters with situations, people and information.

In contrast, in 'active search' methods, information and knowledge is deliberately sought for and scanned for opportunities. There are two search directions here: inward and outward. The starting point for active search can be inward-looking, where one first analyses one's own interests, aspirations, ambitions, dreams, abilities, needs and resources to generate initial ideas (Sarasvathy, 2003; Fiet and Patel, 2008). Only later one directs one's attention outward to opportunity development, enactment, evaluation, and exploitation. Needs and constraints do often serve as starting point in the search for opportunities. For example, many people with young children are looking for income that can be generated from home. Enthusiasm and 
excitement also often serve as starting points. An opportunity to generate income out of a hobby or a special interest can arouse a lot of positive feelings, which subsequently helps to overcome setbacks for the business, to assemble resources, and to convince customers and clients (Baron, 2008).

Alternatively, one's search can be immediately outward-looking, when one searches and scans information about particular markets, industries, changes, trends, or new (technological) knowledge. Outward looking search strategies will depend on the type of opportunity pursued: Arbitrage, franchise, imitation, take-overs, cheaper/better/faster, incremental innovation, or radical innovation opportunities. For example, with arbitrage the search is for price differentials, with franchises for well-run and profitable operations, with imitations for successful businesses, with take-overs for well-performing or underperforming businesses, with cheaper/better/faster opportunities for possibilities to be cheaper/better/faster etc. Another distinction is between the macro and micro levels of analysis. Opportunities are often thought be derive from change (Shane, 2003), for example, demographic, cultural, economic, environmental, or technological change. The opportunities that these change imply often concern the macro level. However, opportunities are also often find at the micro level (Kirzner, 1997), for example, when analyzing what service or retail is needed in a particular neighborhood. In all cases the entrepreneur may have a notion of what the future may hold, and alertness is involved (Kirzner, 2009).

The fourth element concerns the transformation of information and experience, whether encountered in passive or active search, into initial ideas for opportunities (Corbett, 2007). Actively or passively searching for opportunities does not necessarily result in ideas for opportunities. It is here that creativity enters the picture, although many opportunities can be found with little creativity involved, for example when systematically and analytically scanning for arbitrage or franchise opportunities. In creativity theory, it is common to distinguish the insight and the preparation phases in creative processes (Wallas, 1926; Couger, 1995). Refinement of one's opportunity prototype, the development of knowledge, and the building of networks can all be seen as preparational steps in the idea generation process, and even the search strategies described above do not guarantee insights or ideas.

Idea generation can be trained by a host of methods developed and described in the creativity literature, including brainstorming, the use of metaphors and analogies, combining concepts, wishful thinking, and analytical techniques (Couger, 1995; Ward, 2004). Both convergent and divergent thinking can be trained, although dispositional characteristics have an 
impact too (Garfield, Taylor, Dennis and Satzinger, 2001). Couger describes a wide range of methods, some analytical and some intuitive, some for individuals and some for groups. Methods differ in what allows them to stimulate creativity (Smith, 1998).

This brings us to the notion of pre-existing versus created opportunities (Berglund, 2007). Whereas in retrospect everything can be seen as preexisting, this refers in practical terms to the extent to which opportunities are ready-made (as in a simple arbitrage opportunity, when buying a business, or taking out a franchise), or the extent to which the entrepreneur must make an effort to shape, develop and enact the opportunity, whether in creating demand or supply or both (Sarasvathy, Dew, Velamuri, and Venkataraman, 2003). Ideas for opportunities can be seen as the end-point for ready-made opportunities and as a starting point for creation processes. In both cases an initial idea is needed.

Many initial ideas for opportunities can only rudimentarily evaluated because they are only the beginning of a long process of development, adaptation and enactment. Some initial ideas are also end-points: If you see a particular website selling a product well below the price at which it is sold at another auction site, no further investigation is needed. It is simply a matter of buying cheap and selling dear. Other ideas on the other hand are only very vague at first. End point ideas have been referred to as discovery, and starting point ideas as creation (Berglund, 2007). With discovery the opportunity can be said to 'pre-exist': it only needs to be recognized. Uncertainty and ignorance hides the opportunity but once it is found, it can be readily pursued. With creation on the other hand the opportunity is an emerging result. It is not a single insight but rather a process of development and enactment in which uncertainty and ignorance are gradually removed (Berglund, 2007). The details about demand or supply may be unknown, or even both (Ardichvilli, Ray and Cardozo, 2003; Sarasvathy, 2003). Discovery and creation can be seen as a continuum. Whether ideas are the end-point for ready-made opportunities, or a starting point for creation processes, in both cases an initial idea is needed.

The method described in this paper is an outward-looking, active search method. Its main characteristic is that it does not aim for full or complete information, but rather is heuristics inducing, in the sense that snippets of theory and research, selected for their inspirational value and relevant to a particular industry, are used to brainstorm about opportunities for their application in products and services. The next paragraph will describe this heuristic-inducing method in more detail. 


\section{A HEURISTIC-INDUCING METHOD}

In the heuristic-inducing method the strategy is to present information with heuristic value in order to inspire brainstorming about future possibilities (Busenitz and Arthurs, 2007; van Gelderen, 2004). Those looking for opportunities are asked to reflect on this information, and to come up with ideas for applications in new products and services. Rather than presenting a comprehensive overview of information, participants are presented short snippets of information that were selected for their heuristic, inspirational value.

In cognitive psychology, heuristics are defined as mental shortcuts. Busenitz and Arthurs (2007) argue that the use of heuristics helps to learn more quickly and to think differently, which then can lead to innovative insights. Further they state that 'extensive use of heuristics allows one to make substantial leaps in logic and to make approximations regarding the future directions of a specific market' (p. 140). The ability to think heuristically is seen by Alvarez and Barney (2001) as a resource that conveys a distinctive competitive advantage. Entrepreneurs typically operate in ambiguous and uncertain environments and the willingness and confidence to rely on heuristics to piece together limited information may the only way to move forward (Busenitz and Barney, 1997). The speed, efficiency and creativity of heuristic thinking is especially important for OR idea generation. The main drawback of the use of heuristics, inaccuracy, is less relevant to the generation of initial ideas, as initial ideas will be followed up by processes of shaping, adaptation and viability assessment (Berglund, 2007).

A core feature of the heuristics-inducing method is that the researcher contributes to the opportunity recognition process. This happens in two ways: firstly by selecting and presenting research outcomes and issues particular to the industry involved, and secondly by being responsive in the brainstorming that ensues. Thus, the entrepreneurship researcher contributes to the OR process, thereby blurring the boundaries between the researcher and researched. These are usually kept discrete in traditional research, but in the current inquiry the researcher does not maintain an objective, independent distance. One advantage is that the researcher does not show up emptyhanded, just to get data or information. Rather than inquiring about current (best) practice, the entrepreneurship researcher contributes to the process of envisaging future possibilities (Davidsson, 2002).

There are also theoretical reasons that support taking this active role, when seen from to the perspective of the knowledge spillover theory of entrepreneurship (Audretsch, Keilbach and Lehman, 2005). The person 
creating knowledge is often not the person who is exploiting or commercializing that knowledge (Audretsch et al., 2005; McMullen and Shepherd, 2006; Buenstorf, 2007; Sanders, 2007). Public research is often driven by a fascination for the topic or by peer recognition rather than the possibility of commercial application. Audretsch et al. (2005) advance the case that entrepreneurship is the mechanism by which society more fully appropriates its investments in generating new knowledge. According to the knowledge spillover theory of entrepreneurship, knowledge needs to spill over from the creator of knowledge to the entrepreneur. This is exactly what the entrepreneurship researcher is doing in the present research. The approach presented in this paper allows participants to take advantage of research knowledge. The objectivity, independence and distance of the researcher is forfeited. Instead, the researcher is engaged in providing the best possible heuristic information and facilitating a creative and open-ended brainstorm session where ideas are freely discussed. We turn to the dating industry to demonstrate the workings and results of the heuristics-inducing method. Before we describe the method and the workshop outcomes, some background information on the dating industry is presented.

\section{THE DATING INDUSTRY}

Research on loneliness and belonging has shown people to need a social group as well as an intimate partner (Baumeister and Leary, 1996; McWither, 1990; Weiss, 1982). Loneliness can be caused by the absence of one or the other, but without either, people feel profoundly lonely. Relationships are a major source of meaning and purpose (O'Conner and Chamberlain, 1996), especially in Western societies where friendship and romantic love are considered to be of the utmost importance. To be successful in both is part is, for Westerners, a cultural norm. Thus, without friends or an intimate partner, people can easily experience a sense of failure (Adelman and Ahuvia, 1995; Gordon, 1976).

The dating industry attempts to help people to connect to potential friends and partners. The rise of formal, third parties providing services on the dating market has occurred because the informal routes that people have taken to form relationships are failing for some. Several changes have been linked to the emergence of the dating market including an increase in the number of singles, a lack of courtship role models for older people, increasing individualism, urbanization, increased mobility, increased hours of watching television, and ICT developments, which all accrue to potentially make 
people lonelier (Gordon, 1976; Putnam, 2000). However, if so many people are seeking friends or a partner, the problem seems to be more one of coordination than of scarcity. As a consequence, there is increased demand for services that help people to search, match and interact with each other. Solutions to this coordination problem are helped by ICT developments. Hence the emergence of the dating market is not only demand driven, it is also supply driven, given that developments in ICT have opened up possibilities for connecting, matching, and providing interaction for people. Jamieson (2009) reports that in the U.S. half of singletons use dating services, and that around 20\% find long-term romance that way.

The dating market offers a plethora of services. There are many ways to segment the dating market, for example based on age, ethnicity, type of relationship sought, and communication motive (Rathus, Nevid and FichnerRathus, 2005), with specialized agencies emerging to serve particular niches. Ahuvia and Adelman (1992) provide a classification of the dating market by means of the SMI model: Searching Matching Interacting. Searching services include singles advertisements, and internet databases in which people have provided descriptions, pictures or videos of themselves. Searching and matching channels go a step further in that the facilitator provides a matching service. For example, a relationship agency may match people on the basis of information gained in an intake interview, an internet friendship community connects networks of people, and a dating website may match people on the basis of listed characteristics such as age or place of residence. Finally, the interacting services provide facilities for people to interact, for example through dinners, parties, theatre visits, speed dating, or dating games. Training in dating and social skills prepare clients for interaction. Beyond the dating industry in a narrow sense there are many institutions and industries that facilitate contact between people, such as bars, churches and public transport facilities.

\section{METHOD}

Participants. Participants in this research were 10 entrepreneurs running a business in the dating market. Five were located in Australia (Melbourne) and five in New Zealand (Auckland). Businesses were event companies, single parties' organizers, dating websites, speed dating companies, introduction services, and combinations of the above. Eight participants were female and two were male. Their average age was 44 . The businesses were on average seven years old, although with one business which had been in existence for 
32 years, the average age would be 3,2. Three business owners were serial or multiple entrepreneurs in the dating industry. Eight business owners had working experience in service industries.

Sampling Procedure. Dating industry businesses in Auckland and Melbourne were drawn from the Yellow Pages and from Internet Dating Directory Websites. In Auckland the response rate was 50\% and in Melbourne $33 \%$. The lower response rate in Melbourne may be explained by the short time frame during which the Auckland based researcher was around. The businesses were contacted by email. As this study aimed at reporting at the industry level (rather than investigating the idea generating performance of individual business owners), 10 sessions were deemed sufficient.

Approach. In this research a workshop format was used to generate ideas for opportunities in the dating market. An elicitation strategy using two types of information conducive to conjecturing opportunities was deployed. Firstly, social psychological research on what causes attraction and bonding was offered. Examples of this include proximity, appearance, similarity, arousal and cooperation (for an excellent overview see Pines, 2005). Secondly, issues specific to the dating industry were proposed. The issues were identified in newspaper and magazine reports, and especially in online sources about the dating industry (such as the Online Dating Industry Journal, Online Dating Magazine, Online Personals Watch, and various dating weblogs).

Participants were asked to apply the presented information to possible products or services in their market. They were given such prompts as 'how would a service look like that applied this research outcome...?', 'How could this research outcome be applied in your services ...?' 'Can you think of a service that would either enhance or circumvent factor X...?' All sessions were conducted by the author who did not lead the discussions, but nonetheless took an active part in the brainstorming.

The choice and sequence of presented research outcomes and issues was usually similar across the businesses. Sometimes it matched the type of business involved, for example, whether the business only facilitates the initial contact or also subsequent relationship formation. Outer similarity (e.g., looks, dress, physical attractiveness, weight) is important for initiating contact, but inner similarity (e.g., in attitudes, beliefs or personality) is more important for developing the relationship (Murstein, 1976; Rodin, 1987). Interestingly, the Internet makes it possible to change these stages. People can first meet in a chat room, disclose and discover their values, beliefs, attitudes, and have all sorts of exchanges before they meet in real life and see how the other looks. 
Research on factors explaining long-term relationship success was not presented. It would be great for service providers in the dating market to match their clients in such a way that chances of long-term stability of the relationship would be supported. Unfortunately, on the whole this research has generated many inconclusive results (Cate, Levin and Richmond, 2002; Surra, Gray, Cottle, and Boettcher, 2004), giving rise to methodological concerns. There is often a reliance on a single source, and many explanatory variables tend also to become outcome variables. For instance, relationship stability is often explained from commitment or relationship satisfaction. Also the variables that subsequently explain commitment or satisfaction can be conceived as outcome variables. For example, spending time together, or having an active sex life are two such variables, but the fact that a couple is able to spend so much time together and/or maintain an active sex life over a very long period is an achievement in itself.

Confidentiality. Confidentiality was discussed with and assured to all participants. Because direct competitors took part, it was the policy of this research to disclose zero information about other research participants, their firms or their activities. Furthermore, participants were offered the opportunity to keep out of the final report any idea they had a particular affinity to.

\section{OUTCOMES}

\section{Social Psychology Research Outcomes (see Table 1 for an Overview)}

Proximity. Generally speaking, research has concluded that your future partner is most likely not some sort of exotic prince or princess, unless he or she lives in the same apartment block as you, or a few blocks away. Festinger, in his classic 1951 study, showed that of the people living in the same building, those having the apartments facing the inner courtyard knew much more people than those who lived in the apartments facing the street. And Segal (1974) found that many students of the police academy had friends with family names starting with the same letter because the dorm beds were assigned according to last name. One explanation is that the mere fact of being repeatedly exposed to someone creates feelings of trust and safety. Various research has shown that repeated exposure leads to increased ratings of similarity, attractiveness, interestingness, and intelligence (Pines, 2005). This can be extended to situations when someone's physical appearance reminds us of somebody else. 
Prompts: How to incorporate repeated exposure? How to induce people to be in close proximity?

Ideas: Repeat pictures in web based dating; repeated rounds in speed dating; organize events where people meet from previous activities; make the walls in a bar moveable, and adjust for the number of people present, so people have to stand close together.

Outer similarity. Emswiller, Deaux and Willits (1971) had students collect dimes for a phone call wearing either hippie or business attire. They would receive significantly more money when they asked people who were similarly dressed. In the same vein, Suedfeld, Bochner and Matas (1971) found that people marching in anti-war demonstrations would not only sign petitions more often when the requester was similarly dressed, but they would also do that without actually reading what they signed for (or against). We like people who look like ourselves. This may be a matter of genuine and lived experience, but also of stereotypes.

Prompts: How to circumvent stereotyped perceptions based on appearance? How to enhance outward expression?

Ideas: Have an event were all wear the same uniform. Blindfolded speed dating (to prevent stereotypical judgment based on visual clues).

Beauty. Pretty people are better liked, which is no wonder, as they are assigned such favorable traits as kindness, honesty, talent, and intelligence. They are favored in many ways, for example, they get lower punishments in court, or after naughty behavior in the primary school class (Eagly, Ashmore, Makhijani, and Longo, 1991). Attractiveness of business school graduates even predicts their income (Frieze, Olson, and Russell, 1991). (Casual observation suggests that for academic careers the opposite may be true). Physical appearance is decisive for initial attraction, and people decide in $150 \mathrm{sec}-$ onds whether people can still be considered candidates for mating (Pines, 2005 , p. 29). Worldwide, people seem to agree to a large extent on what is physically attractive (Cunningham, Roberts, Barbee, Druen, and Wu, 1995). But further down the beauty scale, subjectivity increases. Also of interest is that for females an unattractive face on a beautiful body gets higher ratings than vice versa (Alicke, Smith, and Klotz, 1986). Of more importance is that although beauty attracts, people tend to choose partners as pretty as themselves, or a little bit prettier (Kalick, 1988). People even choose partners with the same weight (Schafer and Keith, 1990).

Prompts: How to prevent males stereotypically judging females on their looks? How to enhance matching based on beauty? 
Ideas: Combine a weight loss clinic with a dating agency, as (a) daters will do their best to look more attractive (weight loss dating), and (b) people tend to choose partners within their weight class. A dating agency for beautiful people only. Blindfolded speed dating.

Economic/Utility Value. Employing an evolutionary perspective, Buss (1994) and colleagues did a large-scale cross-cultural study involving 10,000 people in 37 different cultures all over the world. Men gave more importance to physical attractiveness (from an evolutionary viewpoint signifying fertility), while women preferred men with money, status, and ambition (from an evolutionary viewpoint signifying the ability to take care of offspring).

Prompts: How to prevent females stereotypically judging males on their economic/utility value? How to enhance matching based on material possessions?

Ideas: Match on the basis of pictures of houses, boats and other belongings; Rate economic position.

Triggers. People sit silently next to each other in a bus, and when they pass something that is striking like a car accident or a fire, they may start a conversation. Another trigger can be an authority who gives permission such as when a presenter asks everybody in the audience to introduce themselves to the person sitting beside them. In normal circumstances people are hesitant to speak with others but may be willing to initiate contact given this kind of trigger.

Prompts: Think of situations where perhaps unconventional ways of contacting and relating take place because they are authorized; Provide triggers for people to initiate contact.

Ideas: Cities can hire actors and actresses to perform all sorts of behaviors that get people to talk. This would be a good way to promote city tourism. Games at singles parties to get people mixing.

Arousal. About 20\% of romantic relationships start in stormy circumstances (Pines, 2005). Apparently, the chances to fall in love are higher when in a state of excitement. It can be a major life change that causes turmoil: moving to a new job, a new country, a new house, getting divorced, getting sick, getting better, etc. Arousal can also be caused by a particular situation or circumstances, such as being on holiday (on a beautiful tropical island, preferably), being drunk, having graduated when spring arrives, or when in danger (for instance in the movie A Life Less Ordinary two angels bring two characters together who in normal circumstances would be highly unlikely 
to fall in love with each other, by forcing them to cooperate in threatening circumstances).

Dutton and Aron (1974) conducted a piece of research using the Capilano Canyon suspension bridge in Vancouver, BC. This bridge is a high arousal setting as it is 5 feet wide and 450 feet long, has low handrails, tilts and sways, and gives the impression that one is about to fall over the side making a 230 foot drop to the rocks and rapids below. Males who crossed the bridge were approached by an attractive female researcher who asked them to participate in a research project. After they had to write a short story, she gave participants her phone number in case they wanted to know more about the project. Eight times more males using this bridge gave Gloria a call (her pseudonym name in the suspension bridge study) than Donna (the same researcher's other pseudonym in the control condition using a solid bridge further upriver only 10 feet above the river with high handrails). A selection effect can not be ruled out, though, with more daring persons walking the suspension bridge as well as making the phone call.

This phenomenon can be explained by Walster and Berscheid's (1971) two factor theory of love. This theory states that there are two components to falling in love: arousal and a label. The emotional label explains the arousal. Emotional labels can be fear, jealousy, and anger but also love. Hence arousal can sometimes be interpreted as being in love.

Prompts: How to induce arousal? Which settings are conducive to arousal?

Ideas: Dating settings that induce arousal: E.g., tango, salsa, or folk dancing; holiday travel dating services; dating services in which candidates come over from abroad.

Inner similarity. Having friends or partners with similar attitudes validates our own beliefs and gives us the pleasant feeling that we are right. Even more importantly, we feel connected with those who share our values, have the same opinions on issues, and find the same things important (Byrne, 1997). We not only feel attracted to similar people, we also assume that we are similar, and sometimes we even fake similarity. Several studies have shown that husbands and wives tend to assume that they are far more similar than they actually are (see Levinger and Breedlove, 1966; Dawes, 1989). We maintain an illusion of similarity, for example, by postponing the discussion of issues that we anticipate to be sensitive, such as for example when a religious Jew and a Catholic feel attracted towards each other, they may both want to discuss their differences in beliefs at a later stage (Rathus, Nevid, and Fichner-Rathus, 2005). 
Duck (1981) emphasizes the importance of agreement as to what friendship or a romantic relationship actually entails. Also important is agreement on the pace and outcome of the relationship. Many relationships and friendships break off because of a divergence in one of these areas. For romantic involvements, similarity in sex role ideology is of essential importance (Grush and Yehl, 1979). If the man believes that the female should just clean the house, cook and tend the children, while the female believes in equality, a romantic relationship is very unlikely to work out. Similarity in sexual attitudes also helps (Smith, Becker, Byrne, and Przybyla, 1993). What is even more fascinating is the research on genetic similarity, which finds that we somehow manage to select mates who have a similar genetic makeup (although not too similar, which would find us attracted to our family members) (Lumpert, 1997). Rushton (1988) examined 1,000 paternity claims brought by women against men who allegedly were the father of their child. In all cases where paternity was proven, there was greater genetic similarity between the real father and the mother, than in the cases were paternity was disproved. Companies like ScientificMatch and GenePartner offer services for daters to have their genetic compatibility tested.

Similarity is in fact the mainstay of matchmaking activities, following the matching hypothesis, which states that people prefer the other to be like themselves or a little bit better. Research provides little evidence of successful outcomes when opposites attract (Pines, 2005; Rathus, Nevid, and Ficher-Rathus, 2005). An exception is sometimes found in the realm of personality. Here sometimes opposites are sought, if compatible, such as in the case of a dominant and a submissive character. Generally, however, people like their friends and partners to have a positive character, especially to be warm and trustworthy (Fletcher et al., 2004). Both men and women look for warmth, trustworthiness, understanding, sensitivity, intelligence, emotional stability, and a sense of humor (Regan, 2003). To a certain extent these wonderful qualities can come about because of self-fulfilling prophecies: when one partner or friend believes that the other has a good trait, the other will start to act accordingly (Murray, Holmes, and Griffin, 1996). Positive illusions about the other's personality help to develop the relationship (Martz et al., 1998). (Still later, putting up with stuff helps (Gottman et al., 1998; Gottman and Levinson, 2000; Rusbult et al., 1991)).

Prompts: How to match on the basis of inner similarity? Which characteristics match best?

Ideas: Match on the basis of genetic similarity; match on the basis of gender role beliefs. 
Cooperation. Sherif et al. (1961) in their famous Robbers Cave experiment showed that boys in a camp readily form in- and out-groups when arbitrarily divided into two groups. Their study showed that in a very short time adversity and hostility between the two factions developed. They also showed that when the two rival groups had to work cooperatively on a certain task for which the input and effort of both groups was necessary, such as pulling a truck needed out of the mud, the groups started to merge and to like each other. People like people with whom they work cooperatively on a task.

Prompts: How to incorporate cooperation in interacting activities?

Ideas: Dating agency that organizes cooperative tasks, e.g., to build a house, to work for a social cause. Cooperation in speed dating by means of speedtasks: e.g., solving a puzzle, building a house from matchsticks. Introduction agencies providing cooperative tasks for first dates.

Associations that cause liking. One avenue of being liked is to associate ourselves with other things or persons that are liked. On the dating market, we can list our preferences for movies, movie stars, pop groups, and novelists. Although not directly disclosing ourselves, rating their popularity reflects on us. Advertisers recognize this by encouraging sales by association and on the dating market we reveal our advertises selves. Another example is the luncheon technique (discussed in Cialdini, 1993). It is good to take friends and dates for lunch or dinner because people tend to like each other's company after having food and drinks. Also, take your date out to a feel-good movie rather than a sad movie (Gouaux, 1971) has shown to have a positive affect making your date will like you better.

Prompts: Which associations can be used that cause liking?

Social Skills. Social skills are a very important factor in attraction and bonding. Lack of social skills is a very important issue for the dating industry as a whole and will be further discussed below. People skilled in assessing others and situations accurately, adopting appropriate styles of communication and body posture, selecting and revealing information in an inviting way, and in pacing the friendship or relationship properly are obviously at an advantage in building relationships (Duck, 1981). There are a broad range of skills involved in creating and building contacts:

Disclosure rules. For example, researchers have explored what is appropriate and inappropriate to disclose in the first 30 seconds, after 1 minute, 5 minutes, 10 minutes, etc. of a real-life first encounter (on the web there are different rules) (Knapp and Vangelisti, 2000). An external example of disclosure is that 
relationships should at some stage achieve public recognition, for example, by meeting other friends in public.

Small talk ability. In the very first parts of initial conversation, small talk ability is very important. This refers to breadth-of-topic coverage rather than talking about topics in-depth (Knapp and Vangelisti, 2000. The website www.branddating.nl was a great dating site that facilitated precisely this activity. The dating situation can be quite awkward and on this site people were matched on the basis of brand preferences. Thus, people's initial conversation could be about toothpaste, sandwich spreads, or sunglasses, rather than discussing loaded topics like the number of children they would like to produce.

Signals of interest. Being friendly, smiling, and having an appealing opening line is inviting when initiating contact. Flirting behavior goes a step further. For females, the hair flip, the skirt hike, the object caress, and applying lipstick can all be courtship behaviors that serve as nonverbal signals to potential partners. Moore (1985) found an additional 48 of those.

Reciprocity. People form a relationship when the attraction is mutual. Reciprocity creates cycles of positive experiences and emotions that reinforce the bond. Curtis and Miller (1986) led people to believe that another person liked or disliked them. The person who thought they were liked, subsequently acted more warmly, were more pleasant, more agreeable, and disclosed more about themselves. Subsequently, the persons who erroneously believed that they were liked, were in fact liked more after the interaction. This sets cycles of reciprocation in motion.

Giving praise. As a rule, we tend to love praise, and like those who provide it, even when it is clearly false. In an experiment conducted by Drachman, deCarufel, and Inkso (1978), men were given feedback from another person who needed a favor from them. Some participants received positive feedback; others negative feedback, and others mixed feedback. When the evaluator gave only positive feedback, he was better liked, even though the men fully realized that he stood to gain from them, and that the positive feedback was randomly given and thus accurate as much as inaccurate. We love to be liked - the fact that someone likes us creates liking in itself.

Prompts: How to incorporate friendship and intimacy skills?

Ideas: The dating agency giving public recognition to emerging relationships. Making information about dating candidates gradually available. 


\section{Special Problems of the Dating Industry (see Table 1 for an Overview)}

The dating industry has a number of special problems in enabling people to connect. First, people do not like to admit that they are lonely. Loneliness is something that happens to other people. Thus, a firm can not state that it caters for lonely people. Similarly, many people do not like to admit that they are alone, and they may feel that they are being a loser using the services of a firm in the dating industry (Adelman and Ahuvia, 1995). In response, the industry as well as the media (T.V. programs, magazines, newspapers) that cater to people living alone have come up with the image of the happy single, whose primary assets are to be free, active, and adventurous.

There is a social stigma to loneliness and even to being alone. One response to this pressure can be that people hang out or even have a relationship with someone just in order to not feel lonely. This is usually not effective in the long run because the other, manipulated person may feel lonely as well. There is also a perception that dating services are being used by losers. This image is presumably held by people who do not consider themselves a loser.

Prompt: How to market your product or service avoiding negative connotations?

Idea: Emphasize the fun aspect, or provide evidence about the general uptake.

Additionally, there is the issue of unruly or obnoxious behavior. If someone proves to be annoying, threatening, or otherwise not conforming to the regulations of the firm, he or she can be removed from the service. But then, being rejected by a dating agency must be the ultimate form of loneliness.

Prompt: How to prevent your business being spoiled by unruly behavior?

Ideas: Use feedback systems like Ebay to filter out non-behaving individuals.

Another issue is that offline activities typically have difficulties attracting males. Those organizing dinners, singles parties, theatre visits and the like have to search widely for men to take part. Any idea that may reduce the barriers for males to take part would be very useful. On the other hand, males are overrepresented at dating websites, who usually have a shortage of females. For dating websites the challenge is to attract women to their site.

Prompt: How can offline activities attract more males, and online services more females? 
Table 1. Overview of Findings.

\begin{tabular}{|c|c|}
\hline Factor & Ideas \\
\hline oximity & $\begin{array}{l}\text { Repeat pictures in web based dating; repeated rounds in } \\
\text { speed dating; organize events where people meet from } \\
\text { previous activities; make the walls in a bar moveable, and } \\
\text { adjust for the number of people present, so people have to } \\
\text { stand close together. }\end{array}$ \\
\hline Outer similarity & $\begin{array}{l}\text { Have an event were all wear the same uniform. Blindfolded } \\
\text { speed dating (to prevent stereotypical judgment based on } \\
\text { visual clues). }\end{array}$ \\
\hline Beauty & $\begin{array}{l}\text { Combine a weight loss clinic with a dating agency, as (a) } \\
\text { daters will do their best to look more attractive (weight } \\
\text { loss dating), and (b) people tend to choose partners within } \\
\text { their weight class. A dating agency for beautiful people } \\
\text { only. Blindfolded speed dating. }\end{array}$ \\
\hline Economic/Utility value & $\begin{array}{l}\text { Match on the basis of pictures of houses, boats and other } \\
\text { belongings; Rate economic position. }\end{array}$ \\
\hline Triggers & $\begin{array}{l}\text { Cities can hire actors and actresses to perform all sorts of } \\
\text { behaviors that get people to talk. This would be a good } \\
\text { way to promote city tourism. Games at singles parties to } \\
\text { get people mixing. }\end{array}$ \\
\hline Arousal & $\begin{array}{l}\text { Dating settings that induce arousal: E.g., tango, salsa, or folk } \\
\text { dancing; holiday travel dating services; dating services in } \\
\text { which candidates come over from abroad. }\end{array}$ \\
\hline Inner similarity & $\begin{array}{l}\text { Match on the basis of genetic similarity; match on the basis } \\
\text { of gender role beliefs. }\end{array}$ \\
\hline Cooperation & $\begin{array}{l}\text { Dating agency that organizes cooperative tasks, e.g., to build } \\
\text { a house, to work for a social cause. Cooperation in speed } \\
\text { dating by means of speedtasks: e.g., solving a puzzle, } \\
\text { building a house from matchsticks. Introduction agencies } \\
\text { providing cooperative tasks for first dates. }\end{array}$ \\
\hline Social Skills & $\begin{array}{l}\text { The dating agency giving public recognition to emerging } \\
\text { relationships. Making information about dating candidates } \\
\text { gradually available. Non-verbal speed dating, e.g., giving } \\
\text { each other a short massage. An impression coach service, } \\
\text { just like the make-over programs on TV, provide advice } \\
\text { and guidance with regard to hair, dress, manners, } \\
\text { conversation, and such. }\end{array}$ \\
\hline Social Stigma & $\begin{array}{l}\text { Emphasize the fun aspect, or provide evidence about the } \\
\text { general uptake. }\end{array}$ \\
\hline Unwanted behavior & $\begin{array}{l}\text { Use feedback systems like Ebay to filter out non-behaving } \\
\text { individuals. }\end{array}$ \\
\hline Gender imbalance & $\begin{array}{l}\text { To offer a combination of online and offline services, and to } \\
\text { use the gender surplus in one modus to compensate for the } \\
\text { gender deficit in the other. }\end{array}$ \\
\hline
\end{tabular}


Idea: To offer a combination of online and offline services, and to use the gender surplus in one modus to compensate for the gender deficit in the other.

Duck (1981) has stated that many people without friends or a partner lack in social skills. Thus, for these people setting them up with someone else is not enough, and is even likely to aggravate the situation, as it was the lack of social skills that caused the person to be without friends in the first place. These people would certainly benefit from training in the many skills involved in building and maintaining relationships.

Prompts: How to match people with poor social skills? Which services can be offered that would improve social skills? How would a service looks relies less on social skills, at least initially?

Ideas: Non-verbal speed dating, e.g., giving each other a short massage. An impression coach service, just like the make-over programs on TV, provide advice and guidance with regard to hair, dress, manners, conversation, and such.

\section{DISCUSSION}

This case study points at a number of opportunities on the dating market. Just the initial aspect of the opportunity recognition process, idea generation, is the focus of attention. It only hints at possibilities and no analysis is done to develop ideas, or to assess their feasibility. Still, entrepreneurial opportunities require novel ideas, and the case study makes a number of suggestions. In addition to pointing at opportunities in this particular market, the case study makes a contribution to the OR literature by showing the workings and value of a heuristic inducing idea generation method.

Most importantly, it shows a method in which the researcher actively contributes to the OR process. By actively selecting and presenting research outcomes, the researcher helps to transfer knowledge from the world of academia to the world of business. Several researchers have by now noted that the person commercializing an idea is often not the same person who originated that idea (McMullen and Shepherd, 2006; Buenstorf, 2007; Sanders, 2007). Especially public research is often driven by recognition rather than by economic rents (Sanders, 2007). According to the knowledge spillover theory of entrepreneurship (Audretsch, Keilbach and Lehman, 2005), knowledge needs to spillover from the creator of knowledge to the entrepreneur, so that society can more fully appropriate its investments in 
generating new knowledge. The approach taken in this study allows participants to take advantage of research knowledge. The objectivity, independence and distance of the researcher is forfeited. Instead, the researcher is engaged in providing the best heuristic information and brainstorm session possible.

Another contribution is the heuristics approach. Rather presenting a comprehensive overview, business owners are presented short bits of information that were selected for their heuristic, inspirational value. This approach involves both the preparational and the insight phases of the creative process (Wallas, 1926), inviting participants to think creatively in how the information can be applied in new product or services in their businesses. Still, we provide the heuristic inputs (information), brainstorm about this information, and record the outputs (ideas), but can not ascertain what the cognitive underpinnings are in the creative process, e.g., is it schema adjustment (Gaglio and Katz, 2001), pattern recognition (Baron, 2006), recombination (Ward, 2004)?

One potential argument against the method presented in this study is that the provided research outcomes are in the public domain, and possibly in some cases not new to the participants, depending on their prior knowledge and experience. Our experience is that even if research and theory are familiar, participants are still able to brainstorm about solutions, applications, and innovations. It is not necessarily the newness of information that leads to opportunity identification. It can also be reflection on known information that allows for connections to be made (Corbett, 2007). Experience cannot be equated to learning, even less to creativity (Ward, 2004). A particular issue can be daily confronted and it may still be fruitful for the agent to be forced to reflect on this issue by a visiting researcher, especially in combination with other information that is added into the mix.

This leads to the notion of under-exploited opportunities noted by Plummer, Haylie, and Godesiabois (2007), who argue that the same opportunity can be exploited in various ways, and that any strategy to pursue an opportunity can still leave room for other, later strategies to pursue the opportunity even further. Buenstorf (2007) makes a similar point when stating that the discovery and exploitation of opportunities are inextricably linked and that a perception-pursuit nexus characterizes new ventures.

Yet another reason why the newness of the presented information is of less concern, is that known information will still be interpreted and evaluated differently. The ideas that a person comes up with depend on his or her idiosyncratic information or beliefs. Shane (2000), and Eckhardt and Shane (2003) have convincingly argued that opportunity recognition is shaped by 
prior knowledge. Different people discover different things because they have diverse information and because evaluation processes are unique to each individual. Participants differ in terms of their experience and life history, and in addition they operate in unique environments and run different kinds of businesses. People also differ in their opportunity prototypes and in how and whether they transform information and experience into new ideas.

This study made use of social psychology research outcomes which is of particular interest in the context of the debate whether opportunities pre-exist or are created. Social science outcomes, in contrast to the natural sciences, do not derive from timeless laws. New services and products in the dating industry are subjective in the sense that individual entrepreneurs create a new dating or relating template (Companys and McMullen, 2007), and they subsequently convince others that this new way of dating is appropriate, feasible, and effective (Chiasson and Saunders, 2005). Yet, especially in the context of the dating industry, it is clear that what is appropriate, feasible and effective is highly dependent on the broader cultural context (Chiasson and Saunders, 2005).

The legitimacy aspects that Chiasson and Saunders (2005) explore play an important role in innovations in the dating market. Because both the dating industry as a whole, as well as specific services have not gained complete acceptance in mainstream society, a new practice runs the risk of ridicule and dismissal. For example, whether a speed dating massage session is seen as appropriate all depends on the agreements amongst the participants. As one owner said, she thought of many new dating or relating practices, and would just give it a try. Experimentation gives rise to feedback which determines what will be retained, adapted or discarded (Sarasvathy, 2001, 2003). What helps, is that it is exactly the authority of the dating industry business owner in his or her role of being the person bringing people together, that makes it possible to explore unconventional ways of dating and relating. This status of authority is often augmented by means of symbol management, for example published testimonials of former customers stating that thanks to the dating business owner, they now have a successful relationship or a close circle of friends.

There are several limitations to this study. As stated above, only the initial aspect of the OR process is the focus of attention. Nothing is done to evaluate ideas or to assess their feasibility. Second, the information presented came from the social sciences and technological developments were not presented to the dating industry business leaders. Third, no systematic evidence was collected on individual 'performance'. Some participants responded better to the workshop set-up than others. However, individual differences in idea 
generation were not the focus of this study, which reports on the industry level.

The last, and most important limitation, is that the impact of an exercise like this is likely to be marginal in most cases. For the dating business owners a visiting academic is just one fleeting small event in their working lives. By far the most knowledge creation and learning takes place in their daily business practice. On the other hand, when the academic does reach out, provides knowledge, and engages in forward looking activities, in a few cases, whether because of the direct engagement with the research participants or because of the readership of subsequent academic or popular reports, there may be a profound positive impact. ${ }^{1}$

Therefore, projects like this could be a worthwhile pursuit in entrepreneurship education. Students do not need to find opportunities, but information that can lead others to recognize opportunities. They can single out a particular change in a particular market or industry, whether it is technological, demographic, environmental, economic, regulatory, cultural, or a business practice. Their research does not need to be exhaustive or comprehensive because it is the essence of the heuristics approach to single out information for inspirational purposes, and not to aim for completeness. In engaging with the business owners the students do not only take but also give, and have a firsthand experience of at least the very initial stage of opportunity recognition. Ultimately, if properly communicated and disseminated, the research may be of benefit to research participants, incumbents, or potential entrants.

\section{REFERENCES}

Adelman, M. B. and Ahuvia, A. C. (1995). Social support in the service sector. The antecedents, processes, and outcomes of social support in an introductory service, Journal of Business Research 32:273-282.

Ahuvia, A. C. and Adelman, M. B. (1992). Formal intermediaries in the marriage market: A typology and review, Journal of Marriage and the Family 54:452-463.

Alicke, M. D., Smith, R. H. and Klotz, M. L. (1986). Judgments of physical attractiveness: The roles of faces and bodies, Personality and Social Psychology Bulletin 12:381-389.

\footnotetext{
${ }^{1}$ A press release on this research led to coverage by national TV, radio stations, and newspapers. One participant was interviewed and quoted as saying that taking part in the research and reading the article was useful. After the media coverage, ideas from this paper were discussed on a variety of dating websites.
} 
Alvarez, S. A. and Barney, J. B. (2001). The entrepreneurship of resource-based theory, Journal of Management 27:755-775.

Ardichvili, A., Cardozo, R. and Ray, S. (2003). A theory of entrepreneurial opportunity identification and development, Journal of Business Venturing 18:105-123.

Audretsch, D. B., Keilbach, M. and Lehmann, E. (2005). The knowledge spillover theory of entrepreneurship and technological diffusion, Advances in the study of Entrepreneurship, Innovation and Economic Growth 16:69-91.

Baker, T. and Nelson, R. E. (2005). Creating something from nothing: Resource construction through entrepreneurial bricolage, Administrative Science Quarterly 50:329-366.

Baron, R. A. (2004). The cognitive perspective: A valueable tool for answering entrepreneurship's basic "why” questions, Journal of Business Venturing 19(2):221-239.

Baron, R. A. (2006). Opportunity recognition as pattern recognition: How entrepreneurs "connect the dots" to identify new business opportunities, Academy of Management Perspectives 104-119.

Baron, R. A. (2008). The role of affect in the entrepreneurial process, Academy of Management Review 33(2):328-340.

Baron, R. A. and Ensley, M. D. (2006). Opportunity recognition as the detection of meaningful patterns: Evidence from the comparison of novice and experienced entrepreneurs, Management Science 52(9):1331-1344.

Baumeister, F. and Leary, M. (1995). The need to belong: Desire for interpersonal attachments as a fundamental human motivation, Psychological Bulletin 117:497-529.

Berglund, H. (2007). Opportunities as existing and created: A study of entrepreneurs in the Swedish mobile internet industry, Journal of Enterprising Culture 15(3): 243-273.

Buenstorf, G. (2007). Creation and pursuit of entrepreneurial opportunities: An evolutionary economics perspective, Small Business Economics 28:323-337.

Busenitz, L. W. and Arthurs, J. D. (2007). Cognition and capabilities in entrepreneurial ventures, in J. R. Baum, M. Frese and R. A. Baron (eds), The psychology of entrepreneurship, Mahwah, New Jersey: Lawrence Erlbaum.

Busenitz, L. W. and Barney, J. B. (1997). Entrepreneurs and managers in large organizations: Biases and heuristics in strategic decision making, Journal of Business Venturing 12:930 .

Buss, D. M. (1994). The strategies of human mating, American Scientist 82:238-249.

Byrne, D. (1997). An overview (and underview) of research and theory within the attraction paradigm, Journal of Social and Personal Relationships 14:417-431.

Cate, R. M., Levin, L. A. and Richmond, L. S. (2002). Premarital relationship stability: A review of recent research, Journal of Social and Personal Relationships 19(2): 261-284.

Chiasson, M. and Saunders, C. (2005). Reconciling diverse approaches to opportunity recognition research using the structuration theory, Journal of Business Venturing 20:747-767.

Choi, Y. R. and Shepherd, D. A. (2004). Entrepreneurs' decisions to exploit opportunities, Journal of Management 30(3):377-395.

Cialdini, R. B. (1993). Influence. The Psychology of Persuasion, New York: Quill.

Companys, Y. E. and McMullen, J. (2007). Strategic entrepreneurs at work: The nature, discovery, and exploitation of entrepreneurial opportunities, Small Business Economics 28:301-322. 
Corbett, A. C. (2007). Learning asymmetries and the discovery of entrepreneurial opportunities, Journal of Business Venturing 22:97-118.

Couger, D. (1995). Creative Problem Solving and Opportunity Finding, Denver: Boyd and Fraser.

Cunningham, M. R., Roberts, A. R., Barbee, A. P., Druen, P. B. and Wu, C. H. (1995). Their ideas of beauty are, on the whole, the same as ours: Consistency and variability in cross-cultural perception of female physical attractiveness, Journal of Personality and Social Psychology 68:261-279.

Curtis, R. C. and Miller, K. (1986). Believing another likes or dislikes you: Behaviors making the beliefs come true, Journal of Personality and Social Psychology 51:284-290.

Davidsson, P. (2002). What entrepreneurship research can do for business and policy practice, International Journal of Entrepreneurship Education 1:1-20.

Dawes, R. M. (1989). Statistical criteria for establishing a truly false consensus effect, Journal of Experimental Social Psychology 25:1-17.

DeCarolis, D. M. and Saparito, P. (2006). Social capital, cognition, and opportunity recognition: A theoretical framework, Entrepreneurship Theory \& Practice 30(1):41-56.

DeTienne, D. R. and Chandler, G. N. (2004). Opportunity identification and its role in the classroom: A pedagogical approach and an empirical test, Academy of Management Learning and Education 3(3):242-257.

Dimov, D. (2007). Beyond the single-person, single-insight attribution in understanding entrepreneurial opportunities, Entrepreneurship Theory \& Practice 31(5):713-731.

Drachman, D., deCarufel, A. and Inkso, C. A. (1978). The extra credit effect in interpersonal attraction, Journal of Experimental Social Psychology 14:458-467.

Duck, S. (1981). Friends, for Life. The Psychology of Close Relationships, Sussex: The Harvester Press.

Dutton, D. G. and Aron, A. P. (1974). Some evidence for heightened sexual attraction under conditions of high anxiety, Journal of Personality and Social Psychology 30: 510-517.

Eagly, A. H., Ashmore, R. D., Makhijani, M. G. and Longo, L. C. (1991). What is beautiful is good, but ... A meta-analytic review of research on the physical attractiveness stereotype, Psychological Bulletin 110(1):109-128.

Eckhardt, J. T. and Shane, S. (2003). Opportunities and entrepreneurship, Journal of Management 29:333-349.

Emswiller, T., Deaux, K. and Willits, J. E. (1971). Similarity, sex, and requests for small favors, Journal of Applied Social Psychology 1:284-291.

Festinger, L. (1951). Architecture and group membership, Journal of Social Issues 7:152-163.

Fiet, J. O. and Patel, P. C. (2008). Entrepreneurial discovery as constrained, systematic search, Small Business Economics 30:215-229.

Fletcher, G. J. O., Tither, J. M., O’Loughlin, C., Friesen, M. and Overall, N. (2004). Warm and homely or cold and beautiful? Sex differences in trading of traits in mate selection, Personality and Social Psychology Bulletin 30(6):659-672.

Frieze, I. H., Olson, J. E. and Russell, J. (1991). Attractiveness and income for men and women in management, Journal of Applied Social Psychology 21:1039-1057.

Gaglio, C. M. and Katz, J. A. (2001). The psychological basis of opportunity identification, Small Business Economics 16:95-111. 
Garfield, M. J., Taylor, N. J., Dennis, A. R. and Satzinger, J. W. (2001). Modifying paradigms - individual differences, creativity techniques, and exposure to ideas in group idea generation, Information Systems Research 12(3):322-333.

Gordon, S. (1976), Lonely in America, New York: Simon and Schuster.

Gottman, J. M., Coan, J., Carrere, S. and Swanson, C. (1998). Predicting marital happiness and stability from newlywed interactions, Journal of Marriage and the Family 60: $5-22$.

Gottman, J. M. and Levenson, R. W. (2000). The timing of divorce: Predicting when a couple will divorce over a 14-year period, Journal of Marriage and the Family 62:737-745.

Gouaux, C. (1971). Induced affective states and interpersonal attraction, Journal of Personality and Social Psychology 20:37-43.

Grush, J. E. and Yehl, J. G. (1979). Marital roles, sex differences and interpersonal attraction, Journal of Personality and Social Psychology 37:116-123.

Jamieson, V. (2009). The dating game, New Scientist 2695:40.

Kaish, S. and Gilad, B. (1991). Characteristics of opportunities search of entrepreneurs versus executives: Sources, interests, general alertness, Journal of Business Venturing 6:45-61.

Kalick, S. M. (1988). Physical attractiveness as a status cue, Journal of Experimental Social Psychology 24:469-489.

Keh, H. T., Foo, M. D. and Lim, B. C. (2002). Opportunity evaluation under risky conditions: The cognitive processes of entrepreneurs, Entrepreneurship Theory \& Practice 27(2):125-148.

Kirzner, I. (1997). Entrepreneurial discovery and the competitive market process: An Austrian approach, Journal of Economic Literature 35(1):60-85.

Kirzner, I. (2009). The alert and creative entrepreneur: A clarification, Small Business Economics 32:145-152.

Knapp, M. L. and Vangelisti, A. L. (2000). Interpersonal Communication and Human Relationships, Boston: Allyn and Bacon.

Levinger, G. and Breedlove, J. (1966). Interpersonal attraction and agreement: A study of marriage partners, Journal of Personality and Social Psychology 3:367-372.

Lumpert, A. (1997). The Evolution of Love, Westport, CT: Prager.

Martz, J. M., Verette, J., Arriaga, X. B., Slovik, L. F., Cox, C. L. and Rusbult, C. E. (1998). Positive illusion in close relationships, Personal Relationships 5:159-181.

McMullen, J. S. and Shepherd, D. A. (2006). Entrepreneurial action and the role of uncertainty in the theory of the entrepreneur, Academy of Management Review 31(1):132152.

McWhirter, B. T. (1990). Loneliness: A review of current literature, with implications for counseling and research, Journal of Counseling and Development 68:417-422.

Moore, M. M. (1985). Nonverbal courtship patterns in women, Ethology and Sociobiology 6:237-247.

Murray, S. L., Holmes, J. G. and Griffin, D. W. (1996). The self-fulfilling nature of positive illusions in romantic relationships: Love is not blind, but prescient, Journal of Personality and Social Psychology 71:1155-1180.

Murstein, B. I. (1976), Who will Marry Whom? New York: Springer.

O'Conner, K. and Chamberlain, K. (1996). Dimensions of life meaning: A qualitative investigation at mid-life, British Journal of Psychology 87:461-477. 
Ozgen, E. and Baron, R. A. (2009). Social sources of information in opportunity recognition: Effects of mentors, industry networks, and professional forums, Journal of Business Venturing 22:174-192.

Pines, A. M. (2005). Falling in Love, New York: Routledge.

Plummer, L. A., Haylie, J. M. and Godesiabois, J. (2007). An essay on the origins of entrepreneurial opportunity, Small Business Economics 28:363-379.

Putnam, R. D. (2000). Bowling Alone, New York: Simon and Schuster.

Rathus, S. A., Nevid, J. S. and Fichner-Rathus, L. (2005). Human Sexuality in a World of Diversity, Boston: Pearson.

Regan, P. (2003). The Mating Game, Thousand Oaks: Sage.

Rodin, J. (1987). Who is memorable to whom? A study of cognitive disregard, Social Cognition 5:144-165.

Rusbult, C. E., Verette, J., Whitney, G. A., Slovik, L. F. and Lipkus, I. (1991). Accommodation processes in close relationships: Theory and preliminary evidence, Journal of Personality and Social Psychology 60:53-78.

Rushton, P. (1988). Genetic similarity, mate choice, and fecundity in humans, Ethology and Sociobiology 9:329-334.

Sanders, M. (2007). Scientific paradigms, entrepreneurial opportunities and cycles in economic growth, Small Business Economics 28:339-354.

Sarasvathy, S. D. (2001). Causation and effectuation: Toward a theoretical shift from economic inevitability to entrepreneurial contingency, Academy of Management Review 26(2):243-263.

Sarasvathy, S. D. (2003). Entrepreneurship as a science of the artificial, Journal of Economic Psychology 24:203-220.

Sarasvathy, S., Dew, N., Velamuri, R. and Venkataraman, S. (2003). Three views of entrepreneurial opportunity, in Z. Acs (ed), Handbook of Entrepreneurship, Kluwer, Dordrecht.

Schafer, R. B. and Keith, P. M. (1990). Matching by weight in married couples: A life cycle perspective, Journal of Social Psychology 130:657-664.

Segal, M. W. (1974). Alphabet and attraction: Unobtrusive measure of the effect of propinquity in a field setting, Journal of Personality and Social Psychology 30:654-657.

Shane, S. (2000). Prior knowledge and the discovery of entrepreneurial opportunities, Organization Science 11:448-469.

Shane, S. and Venkataraman, S. (2000). The promise of entrepreneurship as a field of research, Academy of Management Review 25(1):217-226.

Sherif, M., Harvey, O. J., White, B. J., Hood, W. R. and Sherif, C. W. (1961). Intergroup Conflict and Cooperation: The Robbers Cave Experiment, Oklahoma: University of Oklahoma Book Exchange.

Smith, G. F. (1998). Idea-generation techniques: A formulary of active ingredients, Journal of Creative Behavior 32(2):107-133.

Smith, E. R., Becker, M. A., Byrne, D. and Przybyla, D. P. (1993). Sexual attitudes of males and females as predictors of interpersonal attraction and marital compatibility, Journal of Applied Social Psychology 23:1011-1034.

Suedfeld, P., Bochner, S. and Matas, C. (1971). Petitioner's attire and petition signing by peace demonstrators: A field experiment, Journal of Applied Social Psychology 1:278283. 
Surra, C. A., Gray, C. R., Cottle, N. and Boettcher, T. M. J. (2004). Research on mate selection and premarital relationships: What do we really know? in A. Vangelisti (ed), Handbook of Family Communication, Mahwah, NJ: Erlbaum.

Ucbasaran, D., Westhead, P. and Wright, M. (2009). The extent and nature of opportunity recognition by experienced entrepreneurs, Journal of Business Venturing 24:99-115.

van Gelderen, M. W. (2004). A framework for conjecturing entrepreneurial opportunities. An application to individualization of demand in the undertaking business, Journal of Enterprising Culture 12(4):351-371.

van Gelderen, M. W. (2006). Meaning in life as an opportunity for enterprise, Journal of Enterprising Culture 14(4):307-321.

Wallas, G. (1926). The Art of Thought, New York: Harcourt Brace.

Walster, E. and Berscheid, E. (1971). Adrenaline makes the heart grow fonder, Psychology Today 6:47-62.

Ward, T. B. (2004). Cognition, creativity, and entrepreneurship, Journal of Business Venturing 19:173-188.

Weiss, R. S. (1982). Issues in the study of loneliness, in L. A. Peplau and D. Perlman (eds), Loneliness: A Sourcebook of Current Theory, Research and Therapy, Chapter 5, pp. 71-80, New York: Wiley. 